\title{
Respiratory symptoms, immunological responses, and aeroallergen concentrations at a sawmill
}

\author{
D M G Halpin, B J Graneek, J Lacey, M J Nieuwenhuijsen, P A M Williamson,
} K M Venables, A J Newman Taylor

\begin{abstract}
After identification of a case of extrinsic allergic alveolitis due to exposure to wood dust at a sawmill, all employees at the sawmill where he worked were studied with an occupational, environmental, and symptom questionnaire, spirometry, skin prick tests, and serum specific IgG measurements. Ninety five of current and 14 of 17 ex-sawmill workers were studied. As a basis for comparison, a group of 58 workers from a nearby light engineering factory were also studied. Few women (6) were employed and they were excluded from the analysis. Workers at the sawmill were stratified into high and low exposure groups depending on their place of work. This

We recently described a maintenance engineer who developed wood associated extrinsic allergic alveolitis while working at a Welsh sawmill. ${ }^{1}$ A similar condition-wood trimmer's disease-has been described among sawmill workers in Sweden and has been estimated to affect between $5 \%$ and $10 \%$ of the exposed workforce. ${ }^{2}$ Apart from our index case, wood associated extrinsic allergic alveolitis has not been reported in the United Kingdom. We therefore thought it important to determine whether other workers at the sawmill were affected. An epidemiological, immunological, and environmental investigation was undertaken of both current and ex-workers at the sawmill and of a control population not occupationally exposed to wood or wood products.
\end{abstract} division was supported both by their subjective assessment of the dustiness of their environment and the results of personal dust samples. There were no significant differences between the three groups in age, height, smoking habits, exposure to other causes of extrinsic allergic alveolitis, forced expiratory volume in one second, forced vital capacity, atopic state, or cutaneous reactivity to moulds. In the high exposure group the prevalence of work related cough and nasal and eye symptoms was higher than in the low exposure and comparison groups. The prevalence of work related wheeze was similar in both the high exposure and comparison groups, but was lower in the low exposure group. The prevalences of chronic bronchitis and symptomatic bronchial hyper-reactivity were similar in the high and low exposure groups but were lower in the comparison group. Serum concentrations of specific IgG against extracts of sawdust and Trichoderma koningii were significantly higher in the high exposure group than in the other two groups. The prevalence of symptoms suggestive of extrinsic allergic alveolitis was $4.4 \%$ in the high exposure group, greater than in the low exposure group $(0 \%)$, and the comparison group $(1.9 \%)$. In conclusion extrinsic allergic alveolitis probably occurs in British sawmills, and among the exposed population its prevalence may be as high as that reported in Sweden. The allergen responsible is likely to be from mould growing on the wood and may be from Trichoderma koningii.

(Occup Environ Med 1994;51:165-172)

\section{Materials and methods}

THE SAWMILL

The sawmill, which opened in 1980, cuts timber from all parts of the United Kingdom. The mill site comprises five main buildings: the office building; the green mill with attached sorting shed, saw shop, and maintenance shop; the autostacker; the kiln; and the dry mill. The types of timber cut have been described previously. ${ }^{1}$

About $3300 \mathrm{~m}^{3}$ of timber was cut in the green mill each week. Extraction of sawdust from beneath the band saws, which were enclosed, relied on conveyor belts. There was no atmospheric dust extraction system. Large pieces of wood were cleaned from beneath the machinery each evening, but dust was not regularly cleaned from inaccessible parts of the machines. The whole of the green mill was blown down with compressed air every two to three months.

About $20 \%$ of the cut wood was machined in the dry mill where some was planed or mouldings cut and the rest cut into shorter lengths. Sawdust from these blades was extracted by overhead vents. Less than $5 \%$ of the green mill's output passed through a kiln before reaching the dry mill. The kiln was manually loaded, but was otherwise automatically operated to maintain a temperature of about $60^{\circ} \mathrm{C}$ for three to four days. Humid air was vented from the kiln directly into the atmosphere.

About $5 \%$ of the cut planks were treated with a fungicide in an automatic process with manual loading and unloading of the treatment tank, which was run overnight. The fungicide was a mixture of sodium dichromate $(44.6 \% \mathrm{w} / \mathrm{w})$, copper sulphate $(34.6 \%$ $\mathrm{w} / \mathrm{w})$, and arsenic pentoxide $(19 \cdot 6 \% \mathrm{w} / \mathrm{w})$. 
Saw blades were replaced every three to four hours and were resharpened in the sawshop, where new blades were also made. Most band saw blades were made from steel, but some circular saw blades had tungsten carbide tips.

\section{THE WORKFORCE}

The sawmill employed a total of 100 people distributed between the buildings and outdoors. Two shifts (0600 to 1400 and 1400 to 2200) operated for most of the workforce. Office staff worked from 0900 to 1700 and a few employees worked a night shift from 2200 to 0600 . During each of the day shifts most of the men worked in the green and dry mills, two men worked in the autostacker, and the remainder were outside, either driving vehicles or working in the log yard. Those inside the mills were subject to the highest levels of dust exposure, but although those working outside seemed less exposed to fresh sawdust, they encountered stored logs, sawdust, and wood chips, as well as mulched bark and vapour from the kiln. The maintenance engineers visited all parts of the sawmill and were exposed to old dust on and around the machines.

\section{EX-WORKERS}

The sawmill provided a list of all exemployees other than those employed as casual labour for periods of only a few weeks. During the nine years of operation, 17 workers had left the sawmill, which was by far the largest employer in the area. All of these workers were sent questionnaires at their last known addresses and were invited to attend during the survey for the remaining tests. Those who did not attend were visited at home where practicable.

\section{COMPARISON GROUP}

Workers at a light engineering factory producing large industrial heaters and four wheel drive vehicles were asked to volunteer as a comparison group. The factory employed 110 people and was situated in a similar rural environment to the sawmill. It comprised one large shop floor and attached offices. The workforce consisted of sheet metal workers, lathe operators, welders, paint sprayers (who used two pack polyurethane paint), tool makers, assemblers, warehousemen, and storemen, as well as office staff. Each of these departments was asked to find a number of volunteers to produce a sample with about the same distribution of occupations as at the sawmill.

\section{EXPERIMENTAL DESIGN}

A cross sectional study of the entire workforce at the sawmill and the comparison group was made during one week in October 1989. All subjects gave informed consent before taking part in the survey and the study had been approved by Brompton Hospital ethics comrittee. The subjects completed an occupational, environmental, and smoking questionnaire under supervision. A symptom questionnaire was presented by a doctor blinded to the answers to the first questionnaire, and subjects then had lung function and skin prick tests. Blood samples were also taken.

\section{QUESTIONNAIRES}

The questionnaires contained sections on systemic, respiratory, nasal and conjunctival symptoms, smoking, and occupational history, as well as questions about exposure to other known causes of extrinsic allergic alveolitis (mouldy hay or grain, mushroom growing, and birds). Questions on cough, phlegm, breathlessness, wheezing, and smoking were taken from the Medical Research Council's questionnaire on respiratory symptoms. ${ }^{3}$ Questions on nasal, conjunctival, and flu-like symptoms, weight loss, and fevers were also included. All questions on symptoms asked about the previous 12 months (or the last 12 months of employment at the sawmill). After each of the questions about symptoms were questions about the date of onset of symptoms, whether they improved at weekends or on holiday, and whether there was any seasonal variation. Further questions on wheezing during the four weeks before taking part were taken from a questionnaire that has been validated against histamine bronchial reactivity, ${ }^{4}$ and a positive response to one or more of these questions was used to define symptomatic bronchial hyperreactivity.

Symptoms were called work related if they improved at weekends, or on holiday and if they had started after the subject had joined the sawmill or factory. For the purposes of this survey extrinsic allergic alveolitis was defined as the combination of one or more work related respiratory symptoms (cough or breathlessness) and a constitutional symptom (work related flu like symptoms or unintentional weight loss).

\section{LUNG FUNCTION}

A Vitalograph dry wedge spirometer was used to record forced expiratory manoeuvres from each subject. Subjects were allowed to perform a maximum of six manoeuvres and readings of forced expiratory volume in one second $\left(F E V_{1}\right)$ and forced vital capacity (FVC) were taken. Mean values were calculated from the best two technically satisfactory manoeuvres. From the data for men from both factories multiple regression analysis was performed with age, height, and smoking state and using the residuals for each worker from this line a normalised $\mathrm{FEV}_{1}$ and FVC were calculated with the mean age and height as standards.

\section{SKIN PRICK TESTS}

Skin prick tests were performed with extracts of mixed grass pollen, house dust mite (Dermatophagoides pteronyssinus), cat fur, Alteraria alternata, Aspergillus fumigatus, Cladosporium herbarum, Serpula (Merulius) lacrymans (Bencard), and Mucor mucedo, Aureobasidium (Pullularia) pullulans, 
Penicillium notatum, and Rhizopus nigricans (Allergopharma). A test was called positive if a weal was seen of at least $2 \mathrm{~mm}$ diameter at 10 minutes after testing after subtraction of any weal produced by a control solution. A subject was regarded as atopic if one or more positive reactions were elicited by mixed grass pollen, house dust mite, or cat fur.

\section{AIR SAMPLING}

Airborne dust was sampled with personal dust samplers in the breathing zone of workers who were divided into different exposure groups based on the zoning method of Corn and Esmen. ${ }^{5}$ Concentrations of total airborne dust were measured with seven hole filter holders housing preweighed polytetrafluoroethylene (PTFE) filters $(1.2 \mu \mathrm{m}$ pore size, $25 \mathrm{~mm}$ diameter, Sartorius Instruments Ltd, GB-Belmont, Surrey) and Casella AFC 123 pumps (Casella London Ltd) at a flow rate of $2 \mathrm{l} / \mathrm{min}$. Sampling times ranged from six to eight hours covering a work shift. After sampling, the filters were immediately removed and reweighed on a Sartorius R180D balance so that the dust concentration could be calculated.

\section{DETERMINATION OF AIRBORNE FUNGI}

Air was sampled for fungal spores with both personal and static area air samplers. To assess spore concentrations at different sites around the sawmill, air was sampled with an Andersen sampler. 6 The sampler was held about $1.5 \mathrm{~m}$ above floor level and was operated at a flow rate of $25 \mathrm{1} / \mathrm{min}$. At each site successive sets of six petri dishes containing $2 \%$ malt extract agar, penicillin $(20 \mathrm{IU} / \mathrm{ml}$ medium), and streptomycin (40 $\mathrm{IU} / \mathrm{ml})$, or dichloran rose bengal chloramphenicol agar $^{7}$ were loaded into the Andersen sampler and exposed for 15-60 s. One set of each medium was incubated at $25^{\circ} \mathrm{C}$ and another at $40^{\circ} \mathrm{C}$. All samples were replicated three times and counts for each plate were adjusted for multiple deposition of viable particles beneath jets from Andersen's tables. ${ }^{6}$ Isolates were identified by the appearance of colonies and microscopic morphology from standard texts.

To assess the exposure of individual workers airborne particle samples collected in the breathing zones of workers as described earlier were analysed for the presence of fungal spores. Spores were resuspended by shaking the filter on a whirlimixer (Fisons, Loughborough, Leics) with $5 \mathrm{ml}$ of wash fluid (bacteriological peptone, (1 g); Tween 80, $(0.5 \mathrm{~g})$; inositol, $(20 \mathrm{~g})$; distilled water, (1000 $\mathrm{ml}){ }^{8}$ The suspension was then used to prepare logarithmic dilution series in quarterstrength Ringer's solution and $0.1 \mathrm{ml}$ quantities of suitable dilutions were spread over the agar surface of prepoured petri dishes. Six dishes of $2 \%$ malt extract agar or dichloran rose bengal chloramphenicol agar were inoculated with each dilution and three of each were incubated at $25^{\circ} \mathrm{C}$ and three at $40^{\circ} \mathrm{C}$. Colonies were identified as for Andersen sampler isolates.
SPECIFIC IgG ASSAY

Specific IgG of subtypes IgG1, IgG2, and IgG4 against wood allergens from the sawmill and mould aeroallergens were assayed with a solid phase radioimmunoassay based on the method described by Hay et al with protein $A$ as the tracer. ${ }^{10}$

\section{PREPARATION OF ALLERGENS}

Samples of sawdust were collected from the floor around the green mill bandsaws and mulched bark was collected from the storage pile. Extracts were made with Coca's solution. ${ }^{1}$ These were dialysed and lyophilised before reconstitution in $50 \%$ aqueous glycerol at a final concentration of $500 \mu \mathrm{g} / \mathrm{ml}$. Filtrates from broth cultures of single species of moulds isolated from air samples were also dialysed and lyophilised before similar reconstitution.

\section{SERUM SAMPLES}

Venous blood $(10 \mathrm{ml})$ was collected from subjects and the serum was stored at $-20^{\circ} \mathrm{C}$ until assayed.

\section{RADIOIMMUNOASSAY}

The conditions of the radioimmunoassay were optimised with serum known to contain specific IgG before the assay of serum samples from the survey. Wells on Immulon microtitre plates (Dynatech Laboratories Inc, Chantilly, Virginia, USA) were coated by incubating $100 \mu \mathrm{l}$ of a 1:1000 dilution of antigen in $200 \mathrm{mM}$ sodium carbonate/bicarbonate buffer $\mathrm{pH} 9.2$ for 20 hours in a humid chamber at room temperature. The plates were washed, $50 \mu \mathrm{l}$ duplicate samples of 1 in 500 dilutions of serum were added to the wells, and the plates were again incubated for 20 hours in a humid chamber at room temperature. After further washing $50 \mu \mathrm{l}$ of a $5 \mathrm{ng} / \mathrm{ml}$ solution of ${ }^{125}$ I labelled protein $A$ (Amersham International Plc, Amersham, Bucks) was added to each well. The plates were incubated in a humid chamber at room temperature for five hours before a final wash. The amount of protein A bound to the wells was measured in a gamma counter (Packard Cobra 5 Channel, Canberra Packard, Pangbourne, Berks). Reference tubes to which $50 \mu \mathrm{l}$ of $5 \mathrm{ng} / \mathrm{ml}^{125} \mathrm{I}$ protein $\mathrm{A}$ had been added were also counted and the results of the assay were expressed as the percentage of total counts of ${ }^{125} \mathrm{I}$ protein $\mathrm{A}$ bound to the test wells. The non-specific binding of protein A in tubes coated with the relevant antigen, which had not been incubated with serum, or which had been incubated with fetal serum obtained from placental cord blood was negligible. The non-specific adsorption of test serum antibodies on to the well surface was also negligible under these conditions and blocking of the plates did not seem to be necessary.

\section{STATISTICAL TESTS}

Data from the questionnaires, spirometric measurements, and skin prick test results were coded and entered into a computer 
database. The accuracy of data entry was checked. Statistical analysis was performed with the Minitab statistical program (Minitab Inc, State College, Pennsylvania, USA). Unpaired $t$ tests were used to compare the means of normally distributed data and Kruskal-Wallis one way analysis of variance was used to compare non-parametric data. $\chi^{2}$ tests and Fisher's exact tests were used to compare the frequency with which symptoms or risks of exposure occurred in the groups.

\section{Results}

Ninety five out of the 100 current sawmill workers completed questionnaires and performed spirometry; 88 had skin prick tests and gave a blood sample. Fourteen of the 17 ex-workers were studied and all completed questionnaires, performed spirometry, had skin prick tests, and gave a blood sample. At the comparison factory 58 volunteers were studied and with the exception of two who declined to give blood, all completed all parts of the study.

There were six women among the current employees at the sawmill and six women among the comparison volunteers. As their number was small and they were exclusively involved in secretarial work in offices away from the sawmills and shop floors, the data relating to these women have not been included in the analysis. The data from the current and ex-workers have been combined and analysed as one group. Table 1 shows the number of men employed in different parts of the sawmill.

COMPARISON OF HIGH AND LOW EXPOSURE GROUPS AT THE SAWMILL

The workers' subjective assessment of the dustiness of their environment (on a scale of 0 to 3 ) and the mean dust concentrations measured by personal sampling at the sawmill are broken down by job (table 1). The results of personal sampling largely supported the workers' subjective assessments. The greatest dust concentrations $\left(10.4 \mathrm{mg} / \mathrm{m}^{3}\right)$ were measured in the green mill when Douglas fir was being cut. After discussions with the sawmill management before the survey, the offices, outside areas, dry mill, and autostacker were
Table 2 Median subjective dustiness and percentage reporting work related symptoms, for men in low and high dust jobs, and at the comparison factory

\begin{tabular}{|c|c|c|c|}
\hline & $\begin{array}{l}\text { Low dust } \\
\text { jobs }\end{array}$ & $\begin{array}{l}\text { High dust } \\
\text { jobs }\end{array}$ & $\begin{array}{l}\text { Comparison } \\
\text { factory }\end{array}$ \\
\hline $\begin{array}{l}\text { No } \\
\text { Median subjective }\end{array}$ & 58 & 45 & 52 \\
\hline $\begin{array}{l}\text { dustiness } \\
\text { Work related: }\end{array}$ & 1 & 2 & 2 \\
\hline Cough $(\%)$ & $8 \cdot 6$ & $15 \cdot 6$ & 11.5 \\
\hline Breathlessness (\%) & $3 \cdot 4$ & $11 \cdot 1$ & $3 \cdot 8$ \\
\hline Wheeze (\%) & 3.5 & 20.0 & $19 \cdot 2$ \\
\hline Nose $(\%)$ & $8 \cdot 6$ & $20 \cdot 0$ & $9 \cdot 6$ \\
\hline Eye $(\%)$ & $10 \cdot 3$ & $24 \cdot 4$ & $9 \cdot 6$ \\
\hline Flu like (\%) & 3.4 & 6.7 & 1.9 \\
\hline Chronic bronchitis (\%) & $20 \cdot 7$ & $24 \cdot 4$ & $9 \cdot 6$ \\
\hline Unintentional (\%) & 15.5 & 8.0 & 0.6 \\
\hline $\begin{array}{l}\text { weight loss } \\
\text { Symptomatic bronchial }\end{array}$ & $15 \cdot 5$ & 8.9 & 9.0 \\
\hline hyper-reactivity (\%) & $20 \cdot 7$ & $24 \cdot 4$ & $9 \cdot 6$ \\
\hline
\end{tabular}

classified as low dust environments, and the green mill, maintenance department, and saw shop as high dust environments. Subsequent personal dust sampling and the worker's median subjective assessment of dustiness both supported this division (tables 1 and 2). There were no significant differences between the ages, heights, smoking habits, or exposure to other known causes of extrinsic allergic alveolitis in men in the two exposure groups (table 3). Significantly more workers in the low dust group reported seeing mould than those in the high dust group $(60.3 \% v 37 \cdot 8 \%$, $\mathrm{p}=0.025$ ). Of those observing mould it was seen by $31 \%$ on cut boards, $31 \%$ on logs in the yard, and $22 \%$ in the dry mill. It was seen by $2 \%$ on buildings and $14 \%$ on wood; these $14 \%$ were not able to be more precise.

Table 2 shows the prevalence of work related symptoms, chronic bronchitis (cough productive of sputum for at least three months each year for more than two years), ${ }^{11}$ and unintentional weight loss in these groups. The prevalence of work related cough, wheeze, and nasal and eye symptoms was significantly greater in the high exposure group.

Two workers $(4 \cdot 4 \%)$ in the high dust group had both a work related respiratory symptom and a constitutional symptom and thus fulfilled the criteria for extrinsic allergic alveolitis (as defined for the study). This was significantly more than in the low dust group, where no workers fulfilled these criteria $(\mathrm{p}=0.034)$.

Table 3 Demographic data for men in the three groups

Table 1 Number of employees, median subjective dustiness (assessed on a scale of 0-3), and geometric means of total dust concentrations with $95 \%$ CIs measured with personal samplers for different jobs within the sawmill and at the comparison factory

\begin{tabular}{|c|c|c|c|c|}
\hline & $\begin{array}{l}\text { No of } \\
\text { employees }\end{array}$ & $\begin{array}{l}\text { Subjective } \\
\text { dustiness } \\
\text { (median 0-3) }\end{array}$ & $\begin{array}{l}\text { No of } \\
\text { samples }\end{array}$ & $\begin{array}{l}\text { Personal dust } \\
\left.\text { concentration ( } \mathrm{mg} / \mathrm{m}^{3}\right) \\
\text { geometric mean } \\
(95 \% \mathrm{CI})\end{array}$ \\
\hline Offices & 7 & 0 & 4 & \multirow{8}{*}{$\begin{array}{l}0.24(0.11-0.51) \\
0.71(0.49-1.01) \\
1.13(0.75-1.70) \\
0.81 \\
1.32(0.71-2.49)^{\star} \\
6.25(2.89-13.5) \dagger \\
1.59(0.68-3.71) \\
4.17 \\
2.52(1.22-5.15)\end{array}$} \\
\hline External & 36 & 1 & 15 & \\
\hline Dry mill & 13 & 1 & 6 & \\
\hline Autostacker & 3 & 1 & 2 & \\
\hline Green mill & 22 & 2 & $\begin{array}{l}8 \\
7\end{array}$ & \\
\hline Maintenance & 18 & 2 & 8 & \\
\hline Saw shop & 5 & 2 & 2 & \\
\hline Control & 58 & 2 & 10 & \\
\hline
\end{tabular}

^Measured when cutring spruce.

†Measured when cutting Douglas fir.

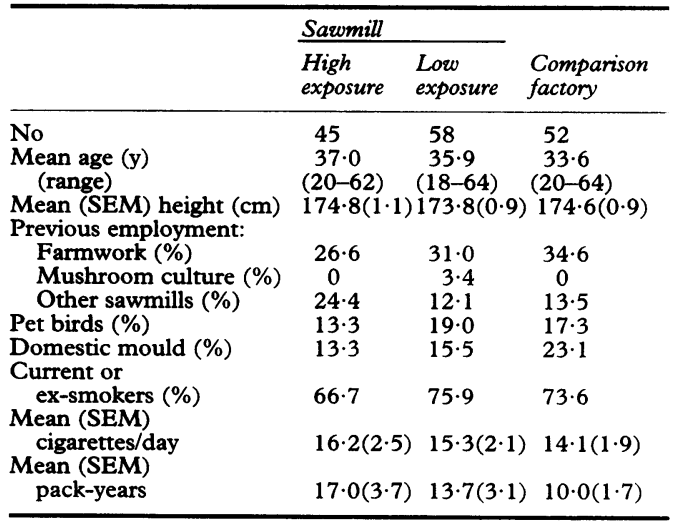


Table 4 Mean (SEM) normalised FEV, and FVC for men in the three groups

\begin{tabular}{llll}
\hline & \multicolumn{2}{l}{ Sawmill } & \\
\cline { 2 - 4 } & $\begin{array}{l}\text { High } \\
\text { exposure }\end{array}$ & $\begin{array}{l}\text { Low } \\
\text { exposure }\end{array}$ & $\begin{array}{l}\text { Comparison } \\
\text { factory }\end{array}$ \\
\hline $\begin{array}{l}\text { Mean normalised }_{\text {FEV }_{1}(1)} \\
\begin{array}{c}\text { Mean normalised } \\
\text { FVC (l) }\end{array}\end{array}$ & $\begin{array}{l}4 \cdot 06(0.09) \\
4.90(0 \cdot 11)\end{array}$ & $4 \cdot 11(0.07)$ & $4 \cdot 13(0.07)$ \\
\hline
\end{tabular}

There were no significant differences in the prevalence of symptomatic bronchial hyperreactivity (table 2), or in the normalised FEV or FVC (table 4). There was also no significant difference in the prevalence of atopy (those with one or more positive reactions to skin prick tests with mixed grass pollen, house dust mite, or cat fur) or cutaneous reactivity to mould extracts among high and low dust workers (table 5).

The results of the IgG binding studies of serum samples from workers against extracts of sawdust from the centre of the logs, mulched bark, Trichoderma koningii, Penicillium glabrum (frequentans), and Aspergillus fumigatus showed that the distribution of the data was skewed. Therefore, for statistical analysis the data were subjected to a $\log _{e}$ transformation to give a normal distribution. Table 6 shows the mean $\log _{e} \%$ binding for workers in the high and low exposure groups at the sawmill. All those with symptomatic extrinsic allergic alveolitis had high concentrations of antibody against fungi. $\log _{e} \%$ binding against sawdust and Trichoderma koningii was significantly greater in men in the high exposure group than in the low exposure group. Among all sawmill workers $\log _{e} \%$ binding against sawdust, mulched bark, Trichoderma koningii, and Aspergillus fumigatus was significantly less .among smokers than non-smokers (table 7).

COMPARISON OF HIGH EXPOSURE GROUP AT THE SAWMILL AND COMPARISON FACTORY

There were no significant differences between the mean ages, height, smoking habits, or exposure to other causes of extrinsic allergic alveolitis in the men in the high exposure group and men at the comparison factory (table 3). There was also no significant difference between the mean \% predicted $\mathrm{FEV}_{1}$ and FVC in the two groups (table 4). Unlike men at the sawmill, no men at the comparison factory had seen mould there.

Significantly more men in the high exposure group at the sawmill reported work related cough, breathlessness, and nasal, ocular, and flu-like symptoms (table 2). There

Table 5 Percentage of men in the three groups who were atopic on skin prick testing and who had at least one positive skin prick test to one or more of eight moulds

\begin{tabular}{llll}
\hline & \multicolumn{2}{l}{ Sawmill } & \\
\cline { 2 - 4 } & $\begin{array}{l}\text { High } \\
\text { exposure }\end{array}$ & $\begin{array}{l}\text { Low } \\
\text { exposure }\end{array}$ & $\begin{array}{l}\text { Comparison } \\
\text { factory }\end{array}$ \\
\hline Atopic (\%) & 57.5 & $39 \cdot 2$ & $43 \cdot 1$ \\
Mould positive (\%) & 19.5 & 11.5 & 22.4 \\
\hline
\end{tabular}

Table 6 Mean (SEM) $\log _{e} \%$ binding of specific IgG against extracts of antigens in the three groups

\begin{tabular}{llll}
\hline & High exposure & Low exposure & $\begin{array}{c}\text { Comparison } \\
\text { factory }\end{array}$ \\
\hline Sawdust & $2 \cdot 49(0 \cdot 18)$ & $1 \cdot 79(0 \cdot 12)$ & $1 \cdot 71(0.06)$ \\
Mulched bark & $3 \cdot 41(0.08)$ & $3 \cdot 22(0.04)$ & $3 \cdot 26(0.04)$ \\
Trichoderma koningii & $3 \cdot 05(0 \cdot 12)$ & $2 \cdot 71(0.08)$ & $2 \cdot 76(0.06)$ \\
Penicillium glabrum & $2 \cdot 41(0.07)$ & $2 \cdot 50(0 \cdot 11)$ & $2 \cdot 51(0.06)$ \\
Aspergillus fumigatus & $2 \cdot 56(0.05)$ & $2 \cdot 39(0.03)$ & $2 \cdot 50(0.05)$ \\
\hline
\end{tabular}

was no significant difference in the prevalence of work related wheeze. There was a higher prevalence of chronic bronchitis and symptomatic bronchial hyper-reactivity in the high exposure group than at the comparison factory, but there was no significant difference between the prevalence of unintentional weight loss. There were no significant differences between the prevalence of atopy or cutaneous reactivity to mould extracts in the high exposure group and at the comparison factory (table 5). A higher proportion of the men in the high exposure group had symptoms suggestive of extrinsic allergic alveolitis than at the comparison factory $(4.4 \% v$ $1.9 \%)$.

The $\log _{\mathrm{e}} \%$ binding values against sawdust and Trichoderma koningii were significantly higher in the high exposure group at the sawmill than in the low exposure and comparison groups (table 6 ). The $\log _{e} \%$ binding against Trichoderma koningii was high in all those men at the sawmill with symptoms suggestive of extrinsic allergic alveolitis.

\section{FUNGAL SPORE COUNTS}

Concentrations of fungal spores collected by personal dust sampling varied considerably between the different occupational groups (table 8). Concentrations similar to or less than those measured in the comparison factory were found in the sawmill offices, outside, autostacker, and sawshop samples. Significantly larger concentrations were found in the dry and green mills. Maintenance workers were also heavily exposed (table 8). Penicillium species were the most numerous fungi in nearly all samples taken at the sawmill but their numbers were small in the sawmill offices and in the comparison factory. Aspergillus fumigatus was also common at all sites in the sawmill but less common in the offices, the autostacker, and in the comparison factory. Trichoderma, Stilbella and Talaromyces species were numerous at some sites, although numbers of Stilbella were very variable with one sample yielding very large numbers of colonies accounting for almost all isolates in a group.

Table 7 Mean (SEM) $\log _{e} \%$ binding of specific IgG against extracts of antigens in smoking and non-smoking men at the sawmill

\begin{tabular}{lll}
\hline Antigen & Non-smokers & Smokers \\
\hline Sawdust & $2 \cdot 91(0 \cdot 23)$ & $1 \cdot 79(0 \cdot 10)$ \\
Mulched bark & $3 \cdot 52(0 \cdot 09)$ & $3 \cdot 22(0 \cdot 05)$ \\
Trichoderma koningii & $3 \cdot 27(0 \cdot 13)$ & $2 \cdot 70(0 \cdot 08)$ \\
Penicillium glabrum & $2 \cdot 07(0 \cdot 09)$ & $1 \cdot 90(0 \cdot 05)$ \\
Aspergillus fumigatus & $2 \cdot 41(0 \cdot 07)$ & $2 \cdot 33(0 \cdot 04)$ \\
\hline
\end{tabular}


Table 8 Mean concentrations of different fungi and mean total concentration of fungi (colony forming units (cfu) $/ \mathrm{m}^{3}$ air) in the breathing zones of workers in different parts of the sawmill and in the control factory

\begin{tabular}{|c|c|c|c|c|c|c|c|c|}
\hline & Offices & Outside & $\begin{array}{l}\text { Dry } \\
\text { mill }\end{array}$ & $\begin{array}{l}\text { Auto- } \\
\text { stacker }\end{array}$ & $\begin{array}{l}\text { Green } \\
\text { mill }\end{array}$ & $\begin{array}{l}\text { Main- } \\
\text { tenance }\end{array}$ & $\begin{array}{l}\text { Saw } \\
\text { shop }\end{array}$ & Control \\
\hline $\begin{array}{l}\text { No of air sampl } \\
\text { analysed } \\
\text { Penicillium } \\
\text { Aspergillus }\end{array}$ & $\begin{array}{r}s \\
2 \\
148\end{array}$ & $\begin{array}{r}7 \\
4501\end{array}$ & $\begin{array}{r}4 \\
9462\end{array}$ & $\begin{array}{r}1 \\
2330\end{array}$ & $\begin{array}{r}7 \\
8700\end{array}$ & $\begin{array}{r}4 \\
4920\end{array}$ & $\begin{array}{r}1 \\
4400\end{array}$ & $\begin{array}{r}5 \\
602\end{array}$ \\
\hline $\begin{array}{l}\text { fumigatus } \\
\text { Trichoderma } \\
\text { Talaromyces } \\
\text { Cladosporium } \\
\text { Aureobasidium } \\
\text { Paecilomyces } \\
\text { Rhizopus } \\
\text { Stibella } \\
\text { Mucor }\end{array}$ & $\begin{array}{r}355 \\
97 \\
123 \\
28 \\
- \\
= \\
-\end{array}$ & $\begin{array}{r}1262 \\
221 \\
683 \\
266 \\
7 \\
123 \\
212 \\
40 \\
38\end{array}$ & $\begin{array}{r}1006 \\
4062 \\
1084 \\
104 \\
- \\
-6 \\
18033 \\
20\end{array}$ & $\begin{array}{r}520 \\
26 \\
26 \\
26 \\
- \\
- \\
\overline{26} \\
869\end{array}$ & $\begin{array}{r}3049 \\
3489 \\
263 \\
619 \\
1320 \\
815 \\
8384 \\
124\end{array}$ & $\begin{array}{r}3609 \\
2007 \\
650 \\
543 \\
217 \\
219 \\
159 \\
262 \\
26\end{array}$ & $\begin{array}{r}3600 \\
264 \\
-\overline{879} \\
264 \\
879 \\
-\overline{3560} \\
-\end{array}$ & $\begin{array}{r}738 \\
85 \\
19 \\
1000 \\
- \\
- \\
3120 \\
-\end{array}$ \\
\hline Total & 1009 & 8891 & 33088 & 5038 & 27120 & 18872 & 13518 & 6646 \\
\hline
\end{tabular}

$-=$ Not detectable

Table 9 Mean concentration of airborne fungi $\left(c f u / m^{3}\right)$ in different parts of the sawmill as determined by Andersen sampler

\begin{tabular}{|c|c|c|c|c|c|c|}
\hline & $\begin{array}{l}\text { Log } \\
\text { yard }\end{array}$ & $\begin{array}{l}\text { Bark } \\
\text { store }\end{array}$ & $\begin{array}{l}\text { Bark } \\
\text { stripper }\end{array}$ & $\begin{array}{l}\text { Dry } \\
\text { mill }\end{array}$ & $\begin{array}{l}\text { Green } \\
\text { middle }\end{array}$ & $\begin{array}{l}\text { Mill } \\
\text { end }\end{array}$ \\
\hline $\begin{array}{l}\text { Penicillium } \\
\text { Aspergillus }\end{array}$ & 1520 & 1440 & 16000 & 1200 & 2720 & 2880 \\
\hline $\begin{array}{c}\text { fumigatus } \\
\text { Trichoderma }\end{array}$ & $\begin{array}{r}60 \\
240\end{array}$ & $\begin{array}{l}380 \\
420\end{array}$ & $\begin{array}{l}160 \\
160\end{array}$ & $\begin{array}{l}120 \\
200\end{array}$ & $\begin{array}{r}80 \\
240\end{array}$ & $\begin{array}{l}800 \\
720\end{array}$ \\
\hline Talaromyces & 380 & 40 & 80 & 120 & 80 & 240 \\
\hline Cladosporium & - & - & - & - & 160 & - \\
\hline Aureobasidium & - & - & - & - & - & - \\
\hline $\begin{array}{l}\text { Paecilomyces } \\
\text { Rhizopus }\end{array}$ & $\begin{array}{l}80 \\
40\end{array}$ & $\begin{array}{l}40 \\
60\end{array}$ & 20 & $\overline{120}$ & $\begin{array}{r}240 \\
80\end{array}$ & $\begin{array}{r}80 \\
800\end{array}$ \\
\hline $\begin{array}{l}\text { Rhizopus } \\
\text { Stilbella }\end{array}$ & $\begin{array}{r}40 \\
600\end{array}$ & $\begin{array}{l}60 \\
80\end{array}$ & $\begin{array}{l}160 \\
120\end{array}$ & $\begin{array}{l}120 \\
120\end{array}$ & $\begin{array}{r}80 \\
2160\end{array}$ & $\begin{array}{r}800 \\
80\end{array}$ \\
\hline Mucor & - & - & - & 120 & 240 & - \\
\hline Total & 4210 & 3700 & 17020 & 2840 & 8960 & 7120 \\
\hline
\end{tabular}

Table 9 shows the numbers of fungal spores collected by the Andersen sampler at different sites throughout the sawmill. Penicillium species, Aspergillus and Trichoderma were again commonly isolated at all sites. In general the prevailing concentrations were lower than those measured with personal samplers but extremely large concentrations of Penicillium spores were measured near to the automatic debarker.

\section{Discussion}

Occupational exposure to softwood dust is one of the areas still to be reviewed under the 1988 Control of Substances Hazardous to Health (COSHH) regulations and there is currently no maximum exposure limit; however, suggested limits have been published for guidance. ${ }^{12}$ With the exception of workers in the sawshop and in the green mill when cutting Douglas fir, dust concentrations were below the suggested exposure limit (eight hour time weighted average) for softwood dust of $5 \mathrm{mg} / \mathrm{m}^{3} .^{12}$ It is likely that some of the dust collected by personal samplers worn by men in the sawshop was metallic, from the saws, so that their exposure to wood dust might also be less than the suggested limit.

Both the results of personal dust sampling and the workers own subjective assessment of the dustiness of their environment supported our stratification into high and low exposure groups at the sawmill.

Significantly more men reported work related mucosal irritation (eye and nose) in the high exposure group at the sawmill than in the low exposure group or at the comparison factory and this is in keeping with other studies of woodworkers. ${ }^{13} 14$

The prevalence of symptomatic extrinsic allergic alveolitis among the high exposure group at the sawmill (4.4\%) suggests that wood associated alveolitis may occur as often in British sawmills as in Swedish sawmills. ${ }^{2}$ No cases of extrinsic allergic alveolitis occurred in men in low dust jobs, suggesting that exposure to wood dust was an important aetiological factor.

The finding that work related wheeze was more prevalent in the comparison and high exposure groups than in the low exposure group suggests that there were sensitisers or irritants in the dust at both sites; at the sawmill these were likely to be in the wood dust, at the comparison factory these may have been related to paint spraying or welding. The fact that the prevalence of symptomatic bronchial hyper-reactivity was similar in both groups at the sawmill and was higher than at the comparison factory, suggests that occupational exposure to sensitisers at the sawmill may be responsible for the development of bronchial hyper-reactivity. Although certain hardwood dusts are known to be potential sensitisers, softwood dusts are not generally considered to be important causes of occupational asthma ${ }^{15}$ although they have been recognised as causes of occupational dermatitis. ${ }^{16}$ Extrinsic allergic alveolitis and wheeze caused by exposure to the same allergen has previously been described ${ }^{17}$ but is uncommon.

Swedish woodtrimmer's disease is thought to be caused by exposure to moulds growing on wood, the growth of which is nurtured by kiln drying. ${ }^{218}$ Only a small proportion of the wood at this sawmill was kiln dried, but half of the sawmill workers had seen mould around the mill, mostly on the unsawn logs in the yard, or on boards being cut in the dry mill. Measurements of airborne spores showed that the largest concentrations occurred near to the automatic debarker and in the green mill. This is consistent with the finding that most wood mould grows in the area between the bark and the wood $^{1920}$ so that spores will be dispersed when high energy teeth rip off the bark or cut the outer layers of the stripped $\log$. Despite the finding of spontaneous heat generation by the pile of mulched bark (presumably due to decomposition of the bark by fungi) spore concentrations nearby were no greater than in the rest of the log yard and were about half the concentrations found in the green mill. The results of personal sampling are in broad agreement with these findings.

At almost all sites the three most commonly isolated fungi were Penicillium species, Aspergillus fumigatus, and Trichoderma species. Penicillium species and Aspergillus fumigatus were also the two most abundant fungi at the comparison factory although fewer in number, but Trichoderma species were uncommon. Total concentrations of fungal colony forming units were of the same order 
as the mean daily concentration of fungal spores determined microscopically, in Cardiff, less than 50 miles from the sawmill. ${ }^{21}$ These are probably somewhat lower than concentrations at inland sites, ${ }^{22}$ but concentrations determined by culturing are also lower than those determined microscopically as not all airborne spores are viable. The composition of species in Cardiff differed greatly, however, from that found in the sawmill. In outdoor air by day, Cladosporium is usually predominant and spores of Aspergillus and Penicillium type are relatively few. At the sawmill and in the comparison factory, Penicillium predominated with Aspergillus fumigatus, Trichoderma, and, sometimes, Stilbella. The last two genera are particularly characteristic of a timber substrate. Cladosporium, Alternaria species, Aureobasidium pullulans, Penicillium species, Aspergillus species, and Trichoderma species have all been found to be numerous in the air of Canadian ${ }^{23}$ and Swedish sawmills. ${ }^{24}{ }^{25}$ Alternaria species and Aureobasidium pullulans were not common, however, at either the sawmill or the comparison factory. Penicillium and Trichoderma species have also been found to be common aerospores in wood furniture factories. ${ }^{26}$

Penicillium species are ubiquitous fungi occurring in soil ${ }^{27}$ as saprophytes on decaying vegetation and causing decomposition of vegetable matter such as grains and foodstuffs. They have previously been associated with both asthma and extrinsic allergic alveolitis. ${ }^{28}$ Trichoderma is also widespread $^{27} 29$ and is commonly found on wood, wood products, and in soil. ${ }^{30}$

The higher concentrations of IgG against Trichoderma koningii in men in the high exposure group at the sawmill compared with those in the low exposure group or at the comparison factory are likely to reflect exposure to the fungus rather than being indicative of disease. Nevertheless, all those workers with symptoms consistent with extrinsic allergic alveolitis had high concentrations of antibody against Trichoderma koningii. High concentrations of serum antibodies against Trichoderma have also been reported in Finnish sawmill workers. ${ }^{31}$

The mean concentration of IgG against sawdust was also significantly greater in workers in high dust jobs at the sawmill than in those in low dust jobs, or at the comparison factory. The presence of high concentrations of IgG against extracts of sawdust and mulched bark probably also reflects exposure, but concentrations were again high in workers with symptoms of extrinsic allergic alveolitis. The identity of the relevant epitopes in the wood extracts remains unclear. Binding inhibition studies ${ }^{1}$ have shown partial antigenic identity with fungal antigens, in particular Trichoderma, present in the wood presumably as a result of infection but there also seem to be other antigens present, some of which may be constituents of wood itself. Wood is known to contain numerous chemicals capable of producing topical dermatitis ${ }^{13}$ and exposure to one or more of these may be responsible for inducing specific IgG production. As in other studies of extrinsic allergic alveolitis, ${ }^{32}$ the mean specific IgG concentrations were lower in smokers than in nonsmokers.

This study has shown that exposure to wood dust at the sawmill was associated with an increased prevalence of symptoms related to nasal and conjunctival irritation and with a high prevalence of symptomatic bronchial hyper-reactivity. Sawmill workers exposed to high concentrations of dust had more work related respiratory symptoms than those exposed to lower dust concentrations and cases of extrinsic allergic alveolitis only occurred in the more heavily exposed group. As well as being exposed to high concentrations of wood dust, this group was also exposed to high concentrations of fungal spores and had high concentrations of specific IgG against extracts of sawdust and Trichoderma koningii. High exposure to fungal spores, particularly to Trichoderma koningii, seems the most likely cause of extrinsic allergic alveolitis in these sawmill workers.

We acknowledge the help of Mrs E Lambourn and Mrs G Lamond in the execution of this study, and Dr R D Tee in the analysis of the blood samples. We also thank Dr P Vale of EMAS for enlisting the cooperation of the comparison factory and visiting some of the ex-workers.
andisting the cooperation

1 Halpin DMG, Graneek BJ, Turner-Warwick M, Newman Taylor AJ. Extrinsic allergic alveolitis in a sawmil worker: case report and review of the literature. Occup Environ Med 1994;51:160-4

2 Belin L. Sawmill alveolitis in Sweden. Int Arch Allergy Appl Immunol 1987;82:440-3.

3 Medical Research Council. Questionnaire on respiratory symptoms. London: MRC 1976.

4 Venables KM, Farrer NM, Sharp L, Graneek BJ, Newman Taylor AJ. Respiratory symptom questionnaire for asthma epidemiology: validity and reproducibility. for asthma epidemiolo
Thorax 1993;48:214-9.

5 Corn M, Emsen A. Workplace exposure zones for classification of employee exposures to physical and chemical agents. Am Ind Hyg Assoc F 1979; 40:47-57.

6 Andersen AA. New sampler for collection, sizing and enumeration of viable inhaled particles. $\mathcal{F}$ Bacteriol 1958;76:471-84.

7 King AD, Hocking AD, Pitt JI. Dichloran-rose bengal medium for enumeration and isolation of moulds from foods. Appl Environ Microbiol 1979;37:959-64.

8 Eduard E, Lacey J, Karlsson K, Palmgren U, Strom G, Blomquist G. Evaluation of methods for enumerating microorganisms in filter samples from highly contaminated occupational environments. Am Ind Hyg Assoc f 1990;51:427-36.

9 Hay FC, Nineham LJ, Roitt IM. Routine assay for detection of IgG and IgM antiglobulins in seronegative and tion of $\mathrm{IgG}$ and IgM antiglobulins in seronegative and
seropositive rheumatoid arthritis. BMF 1975;3:203-4.

10 Langone JJ. Use of labelled protein A in quantitative immunological analysis of antigens and antibodies. immunological analysis of antiger

11 Medical Research Council Committee on the aetiology of chronic bronchitis. Definition and classification of chronic bronchitis for clinical and epidemiological purposes. Lancet 1965;i:775-9.

12 Health and Safety Executive. Occupational exposure limits 1989. London: Health and Safety Executive, 1989 (Guidance Note EH 40/89.)

13 Andersen HC, Andersen I, Solgaard J. Nasal cancers, symptoms, and upper airway function in woodworkers. Br f Ind Med 1977;34:201-7.

14 Wilhemsson B, Drettner B. Nasal problems in wood furniture workers: a study of symptoms and physiological variables. Acta Otolaryngol 1984;98:548-55.

15 Enarson DA, Chan-Yeung M. Characterisation of health effects of wood dust exposures. Am 7 Ind Med 1990 17:33-38.

16 Woods B, Calnan CD. Toxic Woods. Br $\mathcal{f}$ Dermatol 1976;95(suppl 13):1-97.

17 O'Brien IM, Bull J, Creamer B, Sepulveda R, Harries M, Burge PS, Pepys J. Asthma and extrinsic allergic alveolitis due to Merulius lachrymans. Clinical Allergy 1978; litis due to
$835-42$.

18 Wimander $\mathrm{K}$, Belin L. Recognition of allergic alveolitis in the trimming department of a Swedish sawmill. 
European fournal of Respiratory Diseases 1980;61(suppl 107):163-8.

19 Levy JF. Colonisation of wood by fungi. In: Liese W, ed. Biological transformation of wood by microorganisms. Berlin: Springer-Verlag, 1975:16-23.

20 Dutkiewicz J. Bacteria, fungi and endotoxin in stored timber logs and airborne sawdust in Poland. Biodeterioration Research 1989;2:533-47.

21 Hyde HA. Atmospheric pollen and spores in relation to allergy. I. Clinical Allergy 1972;2:153-79.

22 Morrow Brown H, Jackson FA. Aerobiological studies based in Derby. III. A comparison of simultaneous pollen and spore counts from the east coast, midlands and west coast of England and Wales. Clincal Allergy 1978;8:611-9.

23 Unligil HH, Shih MSH, Shields JK. Airborne spores at lumber seasoning yards in the lower Ottawa valley. Canadian fournal of Forestry Research 1974;4:301-7.

24 Rennerfeld E. Nagra undersokningar over Luftens halt av svampsporer. Svensk Botanisk Tidskrift 1947;41:283.
25 Mathiesen-Kaarik A. Einige untersuchungen uber den Stockholm. Svensk Botanisk Tidskrift 1955;49:437-59.

26 Wilhelmsson B, Jernodd Y, Ripe E, Holmberg K. Nasal hypersensitivity in wood furniture workers. Allergy 1984;39:586-95.

27 Gilman JC. A manual of soil fungi. 2nd ed. Ames: Iowa State University Press, 1957.

28 Lacey J, Crook B. Fungal and actinomycete spores as pollutants of the workplace and occupational allergens. pollutants of the workplace and occupational allergens.

Ann Occup Hyg 1988,32.515-33.

29 Rifai MA. A revision of the genus Trichoderma Mycological Papers 1979;116:1-56.

30 Onions AHS, Allsopp D, Eggins HOW. Smith's introduc tion to industrial mycology. 7th ed. London: Edward Arnold, 1981.

31 Liira J, Kotimaa M, Husman K. 23rd International Congress on Occupational Health, Montreal, 1990.

32 Warren CPW. Extrinsic allergic alveolitis: a disease commoner in non-smokers. Thorax 1977;32:567-9. 